This article has been scanned by iThenticat No plagiarism detected

Volume 3, Issue 5, October 2021

p. 29-33

\title{
HOW TO CREATE A FOREIGN LANGUAGE LEARNING CURRICULUM WITH A PEDAGOGICAL DIMENSION?
}

\author{
http://dx.doi.org/10.47832/2757-5403.5-3.3
}

Zainab NAZZEE 1

\begin{abstract}
:
Despite of the many changes in the English language learning curriculum in Iraq, teaching English to school students is not just challenging but rather unsuccessful in terms of creating pupils with both a good competence and an accurate performance. The learning process is being replaced with a merely passing one grade to another process with the blessing of no serious effort to locate and solve such a problem,which would result in an illiterate generation in an English language oriented cultures. There are many reasons for such a problem,one of which is the tendency of most English language teachers to treat content of the curriculum as a structure based material, also there are other factors like; the repetition of the same grammatical rules through our the different stages of school years and the predictable questions used,even in high school final exam.Therefor I would like to propose a three -step plan to overcome these difficulties. The first step is to design a functional based curriculum which presents no syntactical rules in the early years of learning English language but only concentrates on communicative and interacting skills. The second step is to use " pedagogical wheel " as a course given in college in a pretraining program for teachers, the third step of our model is to create a reference in the Ministry of Education to connect with all English teachers and provide updated information, advises, aids and share experience among them.
\end{abstract}

Key words: Pedagogical Dimension, English Language, Learning Curriculum.

\footnotetext{
${ }^{1}$ Researcher, Ministry of Education, Iraq, fawaznazzeel@gmail.com, https://orcid.org/0000-0001-8489-7545
} 


\section{Introduction:}

From the very beginning I would like to point out that this original idea is based on years of working with more than one curriculum in teaching English language along with observing other colleagues handling the same materials in multiple ways. Being a teacher doesn't come with a guide book of what to do but with good preparation to help you be creative and adjust your methods of teaching in order to overcome the many and different situations you may face. This project I suggest is, creating a strategy in curriculum design taking the teacher into consideration along with the timing of presenting different activities to the students, not forgetting the roll of the ministry of Education in the entire process. Raising the awareness of the importance of pre-teaching preparation in colleges and institutions is a key point, actually it is the corner stone of the whole project. A new curriculum should come as a solution to the problems both teachers and learners of English language come across ; therefore locating these problems is a vital to fix things and make use of modern technology for that matter. Simulation to how a native speaker acquire his language and master it in an early age with high fluency must be approached carefully and correctly, especially if you want your students to gain both linguistic and pragmatic competence.

\section{Part one: Problems with the way the Ministry of Education change the English Language curriculum.}

The main problem with how the ministry of education look at choosing a new curriculum ( especially for English language) is importing it, i.e. The ministry contracts with foreign firms not taking into consideration the teachers - abilities or at least providing them with the resources and methods to guide them through the new text book. Many articles were written by Iraqi teachers and researchers ( for their M.A. and PHD. Degrees ) concentrated on this very point ; Abdul Razaq O. Al-Galiby wrote an article in 1911 after the presentation of "Iraq Opportunities " which was written by York firm, he wrote that ( this curriculum was not written in Iraq an no one takes the credit for it, it was imported by a comity in the ministry of education ). The curriculum itself was almost perfect and suited to the communicative way, yet the ministry didn't take teachers' training into account, there weren't real workshops to answer all the teachers' questions and help them develop their methods and strategies with the shift of lesson objectives and all what comes along with it. Most teachers used to handle any subject material as a structural based not content based ( which was required of them at that time ); despite the appropriateness of these text books for every stage, the results were not good at all and the standards of education in Iraq decreased.

Another problem that the ministry failed ( and still) to solve is the predictability of minstrel exams, I as a teacher know the type of questions that my students may face in the final exam and even the items which keep on appearing therefor I can give my students a structural based notes to help them pass.

The ministry made another change to " English for Iraq" around 2016 by Garnet Education, with the same problems not solved; the triangle still stands with the three lines:

1. -Imported curriculum.

2. Poor teachers' training.

3. Repeated questions.

Of course these may not be the only problems concerning the ministry from the point of view of other teachers but are the most influential ones. 


\section{Part two: Problems with teachers` preparation.}

Colleges of Education is the place to prepare and train future teachers, of course each university or educational institution teach ELT ( English Language Teaching) in their own course based on the university policy in seeking what's appropriate and modern, this theoretical study has a practical side of about two months course in actual teaching in both intermediate and secondary schools yet when students graduate and practice being teachers, their main question is how to teach certain materials; such as linguistic functions and projects ( important section in text books). New teachers turn into their elderly colleagues for advice, of course not all teachers but most of them use structural based methods and use it even where it weakens the curriculum ; by the way this method only works in the existence of the problems in part one of this research. Now the question of " how to teach ?" is still unanswered only tackled around to be fair ; ( pedagogy, feedback, warm up, break the ice,aims, objectives and the most important term " motivation ") remain anonymous for most teachers. Universities have no coordination with the ministry of education therefor they don't take the Iraqi curriculum their students going to teach into consideration, if such coordination existed there would be a standard course in ELT for all colleges of education as it should be. Another point is pedagogy, not all colleges focus on that particular point and its relation to being a teacher and giving something worth learning . Students in college study many methods of teaching, the thing that most of them don't realize is that these methods are not to choose from but actually to switch from one to another where it's necessary to teach as many of their students inside the classroom, give them better understanding.

Being a good teacher is mastering different methods and even improvise some to achieve the most of the learning process, a teacher should educate himself/herself constantly.

\section{Part three: Problems with the curriculum itself (linguistic and pragmatic competence).}

The major problem with imported curriculum is that it's a way from what we need in our schools, standards for making an English language teaching curriculum should be put by teachers of good experience and still teach in Iraqi schools ; there is an emphasis on linguistic competence ( knowledge) and the same grammatical rules are giving over and over again therefor teachers feel comfortable to teach these rules and students pass because of the simple examples given to them as well as repeated questions, In the course of doing so another important and vital materials are either neglected or not treated properly; functions and projects ; which are crucial to gain pragmatic competence. According to Yule ( 1996.p.34) pragmatic competence is " the ability to deal with meaning as communicated by a speaker and interpreted by a listener and to be able to interpret people's intended meaning "; to clear things a bit I'll give you an example, in functions we teach the students that ' sorry' is a word to apologize, it's stated so in their text book yet native English speakers use it to show condolences. Pragmatic knowledge is the way towards nearly perfect English language speakers, You may know it as discourse analysis, which is another word for taking context into account; so that the same word would differ in meaning in different contexts ; for example

- You are in my seat.

- sorry.

- (sorry means I apologize )

- My uncle died.

- sorry

- sorry means my condolences. 
If these problems are solved, we would end up with textbooks which are suitable to the level we aim our children to achieve.

\section{Part four: The solution}

I would like to propose a strategy of three steps to achieve the most of any change in curriculum, the first step is to design a functional based curriculum with no syntactic ( grammatical ) rules in all stages but grammatical rules should be given in the final years of intermediate and secondary stages, instead concentration should be given to communicative skills and real interaction simulation through activities like projects and language function. The second step is to coordinate with universities so that what is taught as ELT course in all colleges of education all around Iraq is good enough to prepare future teachers for such text books. The third and last step is up to the ministry as well by creating a reference administration for all English teachers to return to for advising and providing practical modal lessons of how to teach certain materials and overcome difficulties that may come across their way, this administration also monitor teachers' activities and creativity and it would be a way to evaluate their work in ways suited after fully considering this idea. Such steps are not impossible to achieve and work with, one comity can do all the planning for a proper curriculum that would raise the standards of teaching English language and as a result would lead to near native perfection of language use. I believe with time and guided by these criterions we will benefit the most out of any change in the curriculum instead of raising more questions and difficulties.

If such a thing is considered real changes would come of it and education in Iraq would restore its past glory and prepare our students for a world which is dominated by English language culture.

\section{Conclusion:}

This research is closer to a proposal than it is to a look into works of other researchers, with this proposal I suggest a local criterions for designing text books suited to the nature and state of both our students and teachers as well, a functional / communicative curriculum is the key to solve problems of language fluency and language use and would show some cultural aspects of English language users and speakers worldwide, teachers would work with their students and guide them as well without giving the impression that they do, of course education in Iraq as well as other countries was influenced by corona-virus and schools were shifted to what is called as " electronic education " where teachers and schools communicate with their students and give them lessons on line which added a new difficulty and created more problems for English language teachers in teaching different materials for their students. I put in front of you this idea which I wish to be considered and applied as well.To conclude the three steps, these are the three points:-

1. Present a functional based materials with no syntax in early stages.

2. Coordination with universities in their ELT courses.

3. The ministry of Education keep a close and updated site or administration to both monitor and advise English language teachers. 


\section{References}

A.O. Al -Galiby, The New English Language Curriculum,An Article published in July 16, 2011, The Site of Ministry of Education.

Dr.Hannan D. Akef, Evaluating the English Textbook " IRAQ OPPORTUNITIES " Book 6 of the 2nd Intermediate stage, University of Baghdad / college of Education for girls /English Department.

D.M.Krebt, An Evaluation of the " English for Iraq " Course for the Fifth Grade Secondary Schools,Iraqi Academic Scientific Journal,2017,Volume, Issue 120 pages 43-60.

M.A. Safa,The Interface between Linguistic and Pragmatic Competence: The case of Disagreement,Scolding,Requests, and Complains.BU Ali Sina University, Hamedan, Iran. 